Article

\title{
A New Half-Salamo-Based Homo-Trinuclear Nickel(II) Complex: Crystal Structure, Hirshfeld Surface Analysis, and Fluorescence Properties
}

\author{
Xiao-Xin An, Qing Zhao, Hao-Ran Mu and Wen-Kui Dong *(B) \\ School of Chemical and Biological Engineering, Lanzhou Jiaotong University, Lanzhou 730070, China; \\ axx1873441338@163.com (X.-X.A.); zq18215194507@163.com (Q.Z.); xiaoran3363@163.com (H.-R.M.) \\ * Correspondence: dongwk@126.com; Tel.: +86-931-4938-703
}

Received: 10 January 2019; Accepted: 15 February 2019; Published: 18 February 2019

\begin{abstract}
A new homo-trinuclear $\mathrm{Ni}(\mathrm{II})$ half-salamo-based complex $\left[\mathrm{Ni}_{3}(\mathrm{~L})_{2}(\mu-\right.$ $\left.\mathrm{OAc})_{2}(\mathrm{OAc})_{2}\left(\mathrm{CH}_{3} \mathrm{OH}\right)_{2}\right] \cdot 2 \mathrm{CH}_{3} \mathrm{OH}$ was synthesized via the reaction of a tridentate ligand $\mathrm{HL}$ (2-[O-(1-ethyloxyamide)] oxime-4-bromophenol) and $\mathrm{Ni}(\mathrm{OAc})_{2} \cdot 4 \mathrm{H}_{2} \mathrm{O}$, and characterized using elemental analyses, IR spectra, UV-Vis absorption spectra, X-ray crystallography, and Hirshfeld analysis. Interestingly, single-crystal $X$-ray analysis showed that the two acetate molecules were bonded simultaneously with the $\mathrm{Ni}$ (II) atoms by mono-dentate chelating and bidentate bridging coordination modes, respectively, and the resulting hexa-coordinate geometries were ultimately formed. Furthermore, the Hirshfeld analysis of the complex was studied. Compared with HL, the complex fluorescence intensity was significantly lowered, indicating that the $\mathrm{Ni}$ (II) ions have fluorescence quenching characteristics.
\end{abstract}

Keywords: half-salamo ligand; homo-trinuclear Ni(II) complex; structure; Hirshfeld surface analysis; fluorescence property

\section{Introduction}

Salen and its derivatives are usually gained via Schiff-base condensation reaction of a diamine with an aldehyde, a ketone or its derivative [1-4]. The coordination environment includes two imine $\mathrm{N}$ atoms and two $\mathrm{O}$ atoms from the aldehyde or ketone, usually phenolic oxygen atoms. Salamo was developed on the basis of changing the type of amine of the salen-type compound, and after introducing an $\mathrm{O}$ atom to the $\mathrm{N}$ atom of the salen-type compound possessing a $-\mathrm{RC}=\mathrm{N}-$ group, the salamo-type compound is more flexible and stable than the salen-type compound [5]. The salamo-type ligands and their metal complexes, due to their unique physical and chemical properties and potential application values, have attracted more and more attention from chemical researchers [6-12]. Therefore, the results of research into these complexes in the fields of catalysts [13-15], biology [16-20], electrochemical processes [21-27], supramolecular structures [28-33], ion recognitions [34-40], magnetic materials [41-47], and luminescence [48-56] are remarkable.

A new trinuclear Ni(II) half-salamo complex was designed and synthesized. The complex is a new symmetric trinuclear $\mathrm{Ni}$ (II) structure. Most of the previously reported complexes were coordinated by one acetate molecule to two metal atoms [57-60]. In this paper, not only were two acetate molecules coordinated to two Ni(II) atoms, but also by bidentate bridging and monodentate chelating coordination modes simultaneously connecting two Ni(II) atoms. Most importantly, Hirshfeld surface analysis was also studied while studying fluorescence properties. 


\section{Experimental}

\subsection{Materials and Measurements}

All solvents and chemicals were obtained from commercial sources and used without further purification. Elemental analyses for nickel(II) were measured by IRIS ER/S-WP-1 ICP atomic emission spectrometer (Elementar, Berlin, Germany), elemental analyses for carbon, hydrogen, and nitrogen were conducted using GmbH VariuoEL V3.00 automatic elemental analysis instrument (Elementar, Berlin, Germany). IR spectra were made via a Bruker VERTEX70 FT-IR spectrophotometer, with samples prepared as CsI (100-500 $\left.\mathrm{cm}^{-1}\right)$ and $\mathrm{KBr}\left(500-4000 \mathrm{~cm}^{-1}\right)$ pellets (Bruker AVANCE, Billerica, MA, USA). The UV-Vis spectra were obtained by a Shimadzu UV-3900 spectrometer (Shimadzu, Tokyo, Japan). The ${ }^{1} \mathrm{H}$ NMR (nuclear magnetic resonance) spectra were measured by German Bruker AVANCE DRX-400/600 spectroscopy (Bruker AVANCE, Billerica, MA, USA). Fluorescence spectra were measured via a F-7000 FL spectrophotometer (Hitachi, Tokyo, Japan). The X-ray single-crystal structure was measured by a SuperNova Dual ( $\mathrm{Cu}$ at zero) four-circle diffractometer.

\subsection{Synthesis of $H L$}

1,2-Bis(aminooxy)ethane was synthesized via a similar method reported earlier in Reference [61]. 5-Bromo-2-hydroxybenzaldehyde $(402.04 \mathrm{mg}, 0.02 \mathrm{mmol})$ in ethanol solution $(40 \mathrm{~mL})$ was slowly added to 1,2-bis(aminooxy)ethane $(368.4 \mathrm{mg}, 0.01 \mathrm{mmol})$ in ethanol $(60 \mathrm{~mL})$ over $1 \mathrm{~h}$. The mixture was heated at $50-55{ }^{\circ} \mathrm{C}$ for $5 \mathrm{~h}$. The solution was concentrated by reduced pressure and the residue was purified via column chromatography with chloroform:ethyl acetate $=20: 1$ gaining the ligand HL:2-[O-(1-ethyloxyamide)]oxime-4-bromophenol (Scheme 1). Yield: $62.5 \%$. m.p.: $60-61{ }^{\circ} \mathrm{C} .{ }^{1} \mathrm{H}$ NMR $\left(400 \mathrm{MHz}, \mathrm{CDCl}_{3}\right) \delta 3.95(\mathrm{t}, J=4.5 \mathrm{~Hz}, 2 \mathrm{H}), 4.36(\mathrm{t}, J=4.5 \mathrm{~Hz}, 2 \mathrm{H}), 5.50(\mathrm{brs}, 2 \mathrm{H}), 6.87(\mathrm{~d}, J=9.0 \mathrm{~Hz}$, $1 \mathrm{H}), 7.25(\mathrm{~d}, J=2.5 \mathrm{~Hz}, 1 \mathrm{H}), 7.37(\mathrm{dd}, J=9.0,2.5 \mathrm{~Hz}, 1 \mathrm{H}), 8.14(\mathrm{~s}, 1 \mathrm{H}), 9.88(\mathrm{~s}, 1 \mathrm{H}) . \mathrm{IR}\left(\mathrm{KBr}, \mathrm{cm}^{-1}\right)$ : $3234(\mathrm{~m}), 2953(\mathrm{~m}), 2895(\mathrm{~m}), 1608(\mathrm{~s}), 1577(\mathrm{~m}), 1475(\mathrm{~s}), 1428(\mathrm{~s}), 1366(\mathrm{~m}), 1261(\mathrm{~s}), 1170(\mathrm{w}), 1054(\mathrm{~s})$, $971(\mathrm{w}), 927(\mathrm{~s}), 836(\mathrm{~m}), 776(\mathrm{~s}), 727(\mathrm{~s}), 676(\mathrm{~s}), 620(\mathrm{~s}), 587(\mathrm{w}), 542(\mathrm{w})$. UV-Vis $\left(\mathrm{CH}_{3} \mathrm{CH}_{2} \mathrm{OH}\right), \lambda_{\max }$ $(\mathrm{nm})\left(\varepsilon_{\max }\right): 218,265$, and $322 \mathrm{~nm}\left(5.0 \times 10^{-5} \mathrm{M}\right)$. Anal. Calcd for $\mathrm{C}_{9} \mathrm{H}_{11} \mathrm{BrN}_{2} \mathrm{O}_{3}(\%): \mathrm{C} 39.29 ; \mathrm{H} 4.03$; N 10.18. Found: C 39.58; H 4.00; N 10.06.<smiles>NOCCONCCONCc1cc(Br)ccc1O</smiles>

$\mathrm{HL}$

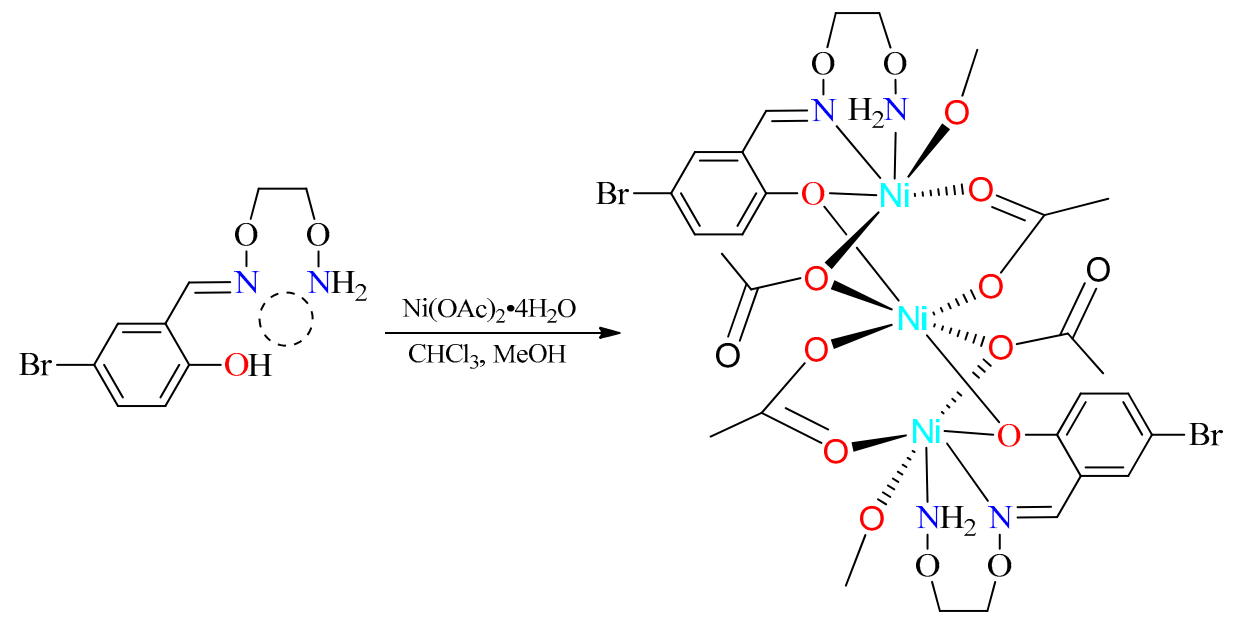

Scheme 1. Synthetic routes to HL and its Ni(II) complex. 


\subsection{Synthesis of the Ni(II) Complex}

A methanol solution $(2.0 \mathrm{~mL})$ of nickel(II) acetate tetrahydrate $(5.50 \mathrm{mg}, 0.02 \mathrm{mmol})$ was added to a trichloromethane solution $(3.0 \mathrm{~mL})$ of $\mathrm{HL}(4.98 \mathrm{mg}, 0.02 \mathrm{mmol})$ at room temperature, and the color of the mixed solution turned light brown immediately. After, the mixed solution was stirred for 3-5 min and then the mixture was filtered. The resulting filtrate was left undisturbed for about one week to gain clear light-yellow block-like crystals suitable for X-ray crystallographic analysis (Scheme 1). Yield: 53.1\%. IR (KBr, cm $\left.{ }^{-1}\right)$ : 3402 (m), 2945 (w), 1596 (s), 1561 (m), 1457 (s), 1386 (s), 1290 (s), $1248(\mathrm{~s}), 1073(\mathrm{~m}), 1032(\mathrm{~m}), 967(\mathrm{w}), 935(\mathrm{w}), 851(\mathrm{w}), 744(\mathrm{~m}), 701(\mathrm{w}), 661(\mathrm{w}), 620(\mathrm{w}), 558(\mathrm{w}), 523$ $(\mathrm{w}), 455(\mathrm{w})$. UV-Vis $\left(\mathrm{CH}_{3} \mathrm{CH}_{2} \mathrm{OH}\right), \lambda_{\max }(\mathrm{nm})\left(\varepsilon_{\max }\right): 226$ and $375 \mathrm{~nm}\left(5.0 \times 10^{-5} \mathrm{M}\right)$. Anal. Calcd for $\mathrm{C}_{30} \mathrm{H}_{48} \mathrm{Br}_{2} \mathrm{~N}_{4} \mathrm{Ni}_{3} \mathrm{O}_{18}$ (\%): C 33.10; H 4.44; N 5.15; Ni 16.17. Found: C 33.32; H 4.21; N 5.11; Ni 16.12.

\subsection{Crystal Structure Determination for the Ni(II) Complex}

X-ray single crystal diffraction data of the $\mathrm{Ni}(\mathrm{II})$ complex was measured at 294.78(16) K with a SuperNova Dual ( $\mathrm{Cu}$ at zero) using a monochromated Mo-Ka radiation $\lambda=0.71073 \AA$. The LP corrections were used to with SAINT program and semi-empirical correction using the SADABS program. The structures were solved using direct methods (SHELXS-2015) [62,63]. The highest difference Fourier map maximum was about 0.7 with a distance of $1.05 \mathrm{~A}$ from Br1. All non-hydrogen atoms were anisotropically refined; all hydrogen atoms were contained at the calculated positions and constrained to ride on their parent atoms. Details of the data collection and refinements of the $\mathrm{Ni}(\mathrm{II})$ complex are summarized in Table 1. CCDC (1889237) contain the supplementary crystallographic data for this paper. The date can be obtained free of charge from the Cambridge Crystallographic Data Centre and www.ccdc.cam.ac.uk/conts/retrieving.html.

Table 1. Crystal data and refinement parameters for the Ni(II) complex.

\begin{tabular}{|c|c|}
\hline Compound & Ni(II) Complex \\
\hline Formula & $\mathrm{C}_{30} \mathrm{H}_{48} \mathrm{Br}_{2} \mathrm{~N}_{4} \mathrm{Ni}_{3} \mathrm{O}_{18}$ \\
\hline Formula weight & 1088.67 \\
\hline Temperature (K) & $294.78(16)$ \\
\hline Wavelength $(\AA)$ & 0.71073 \\
\hline Crystal system & orthorhombic \\
\hline Space group & $P b c n$ \\
\hline$a(\AA)$ & $17.886(2)$ \\
\hline$b(\AA)$ & $9.3664(14)$ \\
\hline$c(\AA)$ & $24.954(4)$ \\
\hline$\alpha\left({ }^{\circ}\right)$ & 90.00 \\
\hline$\beta\left(^{\circ}\right)$ & 90.00 \\
\hline$\gamma\left({ }^{\circ}\right)$ & 90.00 \\
\hline$V\left(\AA^{3}\right)$ & $4180.5(10)$ \\
\hline Z & 4 \\
\hline$D_{\text {calc }}\left(\mathrm{g} \cdot \mathrm{cm}^{-3}\right)$ & 1.730 \\
\hline$\mu\left(\mathrm{mm}^{-1}\right)$ & 3.325 \\
\hline$F(000)$ & 2216 \\
\hline Crystal size (mm) & $0.17 \times 0.15 \times 0.14$ \\
\hline \multirow[t]{2}{*}{$\theta$ Range $\left({ }^{\circ}\right)$} & $3.9870-18.3900$ \\
\hline & $-21 \leq h \leq 19$ \\
\hline \multirow[t]{2}{*}{ Index Ranges } & $-11 \leq k \leq 8$ \\
\hline & $-22 \leq l \leq 29$ \\
\hline Reflections collected & 13,630 \\
\hline Independent reflections & 1967 \\
\hline$R_{\text {int }}$ & 0.1191 \\
\hline Completeness to $\theta$ & $99.8 \%(\theta=24.997)$ \\
\hline Data/restraints/parameters & $3670 / 0 / 263$ \\
\hline GOF & 1.070 \\
\hline
\end{tabular}


Table 1. Cont.

\begin{tabular}{|c|c|}
\hline Compound & Ni(II) Complex \\
\hline $\begin{array}{l}\qquad R[I>2 \sigma(I)] \\
\text { Largest differences peak and hole }\left(\mathrm{e} \AA^{-3}\right)\end{array}$ & $\begin{array}{c}R_{1}=0.0721, w R_{2}=0.1663 \\
0.738 /-0.613\end{array}$ \\
\hline
\end{tabular}

\section{Results and Discussion}

\subsection{IR Spectra}

In the IR spectra (Table 2), HL and its complex show different peaks in the $500-4000 \mathrm{~cm}^{-1}$ region. The $v_{(\mathrm{O}-\mathrm{H})}$ frequency of $\mathrm{HL}$ appeared at $3234 \mathrm{~cm}^{-1}$. This peak disappeared in the $\mathrm{Ni}(\mathrm{II})$ complex, while a new peak appeared at $3402 \mathrm{~cm}^{-1}$ which was assigned to the vibration of methanol molecules. The ligand HL showed a $v_{(\mathrm{C}=\mathrm{N})}$ band at $1608 \mathrm{~cm}^{-1}$, while that of the $\mathrm{Ni}(\mathrm{II})$ complex appeared at 1596 $\mathrm{cm}^{-1}$. For the ligand HL, the $v_{(\mathrm{Ar}-\mathrm{O})}$ band appeared at $1261 \mathrm{~cm}^{-1}$, and that of the $\mathrm{Ni}(\mathrm{II})$ complex was observed at $1248 \mathrm{~cm}^{-1}$ [64]. It can be observed from the data that the characteristic $v_{(\mathrm{C}=\mathrm{N})}$ and $v_{(\mathrm{Ar}-\mathrm{O})}$ frequencies moved to lower frequencies, showing the formation of $\mathrm{Ni}-\mathrm{N}$ and $\mathrm{Ni}-\mathrm{O}$ bonds. The far-infrared spectrum of the $\mathrm{Ni}$ (II) complex also gained in the $500-100 \mathrm{~cm}^{-1}$ region in order to distinguish frequencies owing to the $\mathrm{Ni}-\mathrm{O}$ and $\mathrm{Ni}-\mathrm{N}$ bonds, and $v_{(\mathrm{Ni}-\mathrm{O})}$ and $v_{(\mathrm{Ni}-\mathrm{N})}$ frequencies were found as new peaks at 455 and $532 \mathrm{~cm}^{-1}$ [65], respectively.

Table 2. The major IR spectra of HL and its Ni(II) complex $\left(\mathrm{cm}^{-1}\right)$.

\begin{tabular}{cccccc}
\hline Compound & $v_{(\mathrm{O}-\mathrm{H})}$ & $\boldsymbol{v}_{(\mathrm{C}=\mathrm{N})}$ & $\boldsymbol{v}_{(\mathrm{Ar}-\mathrm{O})}$ & $\boldsymbol{v}_{(\mathrm{Ni}-\mathrm{O})}$ & $\boldsymbol{v}_{(\mathrm{Ni}-\mathrm{N})}$ \\
\hline HL & 3234 & 1608 & 1261 & - & - \\
Complex & 3402 & 1596 & 1248 & 455 & 523 \\
\hline
\end{tabular}

\subsection{UV-Vis Absorption Spectra}

The UV-Vis titration of the Ni(II) complex is depicted in Figure 1. During the UV-Vis titration, we can easily observe that the HL shows three typical absorption peaks at 218, 265, and $322 \mathrm{~nm}$, which can be assigned to the $\pi-\pi^{*}$ transition [66]. With the increase of concentration of $\mathrm{Ni}(\mathrm{II})$ ions, the three typical peaks of HL changed, the peaks at 265 and $322 \mathrm{~nm}$ disappeared. Meanwhile, a new peak appeared at $375 \mathrm{~nm}$, and attributed to HL to metal LMCT [67-69], which is characteristic of the transition metal salen-type complexes. In addition, when the ratio of HL to metal ions is lower than 2:3, the absorption intensity increases linearly with the concentration of $\mathrm{Ni}$ (II) ions, and when it reaches $3: 2$, the absorption spectrum no longer changes with the increase of concentration of $\mathrm{Ni}(\mathrm{II})$ ions, indicating that the titration reaches the end point. In the UV-Vis titration, we formulated the ligand HL to a concentration of $5.0 \times 10^{-5} \mathrm{M}$, and the $\mathrm{Ni}(\mathrm{OAc})_{2} \cdot 4 \mathrm{H}_{2} \mathrm{O}$ was formulated to a concentration of $1.0 \times 10^{-3} \mathrm{M}$.

\subsection{The Crystal Structure Description}

The crystal structure of the homo-trinuclear Ni(II) complex is given in Figure 2, and bond lengths and angles are given in Table 3. X-ray crystallographical analysis revealed that the $\mathrm{Ni}$ (II) complex crystallizes in the orthorhombic, space group $P b c n, \mathrm{Z}=4$, all bond lengths are in normal ranges [22,41]. The complex $\left[\mathrm{Ni}_{3}(\mathrm{~L})_{2}\left(\mu_{2}-\mathrm{OAc}\right)_{2}(\mathrm{OAc})_{2}\left(\mathrm{CH}_{3} \mathrm{OH}\right)_{2}\right] \cdot 2 \mathrm{CH}_{3} \mathrm{OH}$ is formed by coordination of HL with $\mathrm{Ni}(\mathrm{OAc})_{2} \cdot 4 \mathrm{H}_{2} \mathrm{O}$, the $\mathrm{Ni}(\mathrm{II})$ complex includes three $\mathrm{Ni}(\mathrm{II})$ atoms and two completely deprotonated ligand (L) ${ }^{-}$units. The complex presents a centrally symmetric structure, the central $\mathrm{Ni}(\mathrm{II})$ atom $(\mathrm{Ni2})$ is hexacoordinated, consists of six $\mathrm{O}$ atoms $\left(\mathrm{O} 1, \mathrm{O} 4, \mathrm{O} 26\right.$ and $\left.\mathrm{O} 1^{\#}, \mathrm{O}^{\#}, \mathrm{O} 26^{\#}\right)$ from the two fully deprotonated ligand $(\mathrm{L})^{-}$units and four acetate molecules with two kinds of coordination modes, together formed an octahedral coordination geometry. Then, the coordination spheres of the two terminal $\mathrm{Ni}(\mathrm{II})$ atoms (Ni1 and $\mathrm{Ni1}^{\#}$ ) are both surrounded by two imine $\mathrm{N}$ atoms (N9 and N20), 
one phenol $\mathrm{O}$ atom $(\mathrm{O} 4)$, one $\mathrm{O}$ atom $(\mathrm{O} 3)$ from the coordinated methanol molecule, and two $\mathrm{N}$ atoms $(\mathrm{O} 1$ and $\mathrm{O} 2)$ from two acetate molecules with two kinds of coordination modes to complete together their slightly distorted octahedral geometries.

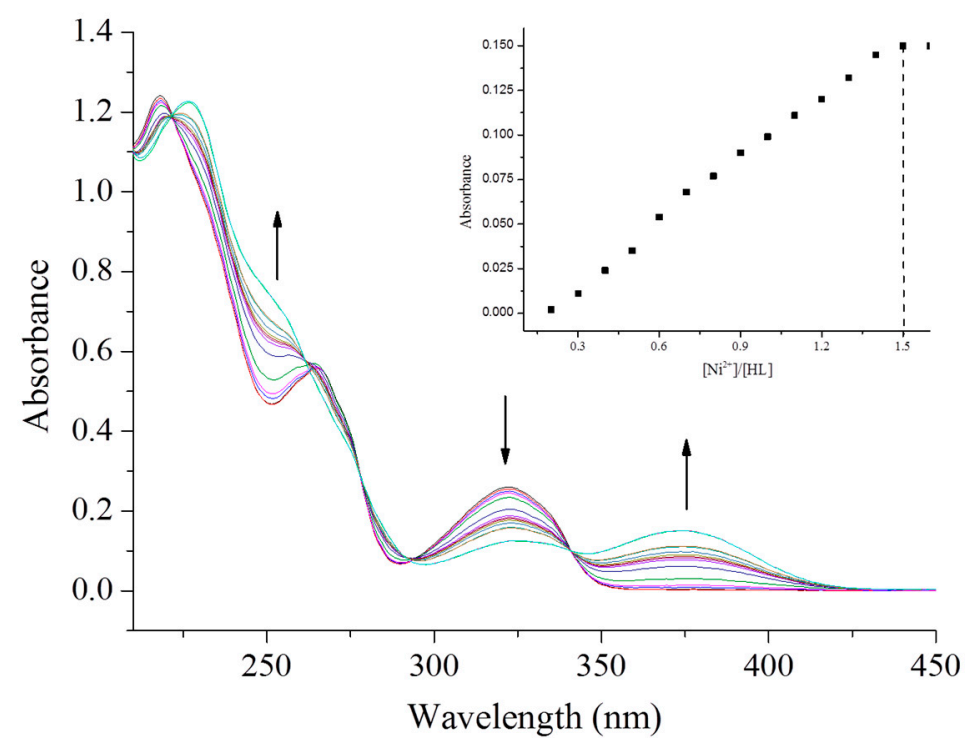

Figure 1. The UV-Vis titration spectra of the Ni(II) complex $\left(\mathrm{cm}^{-1}\right)$.
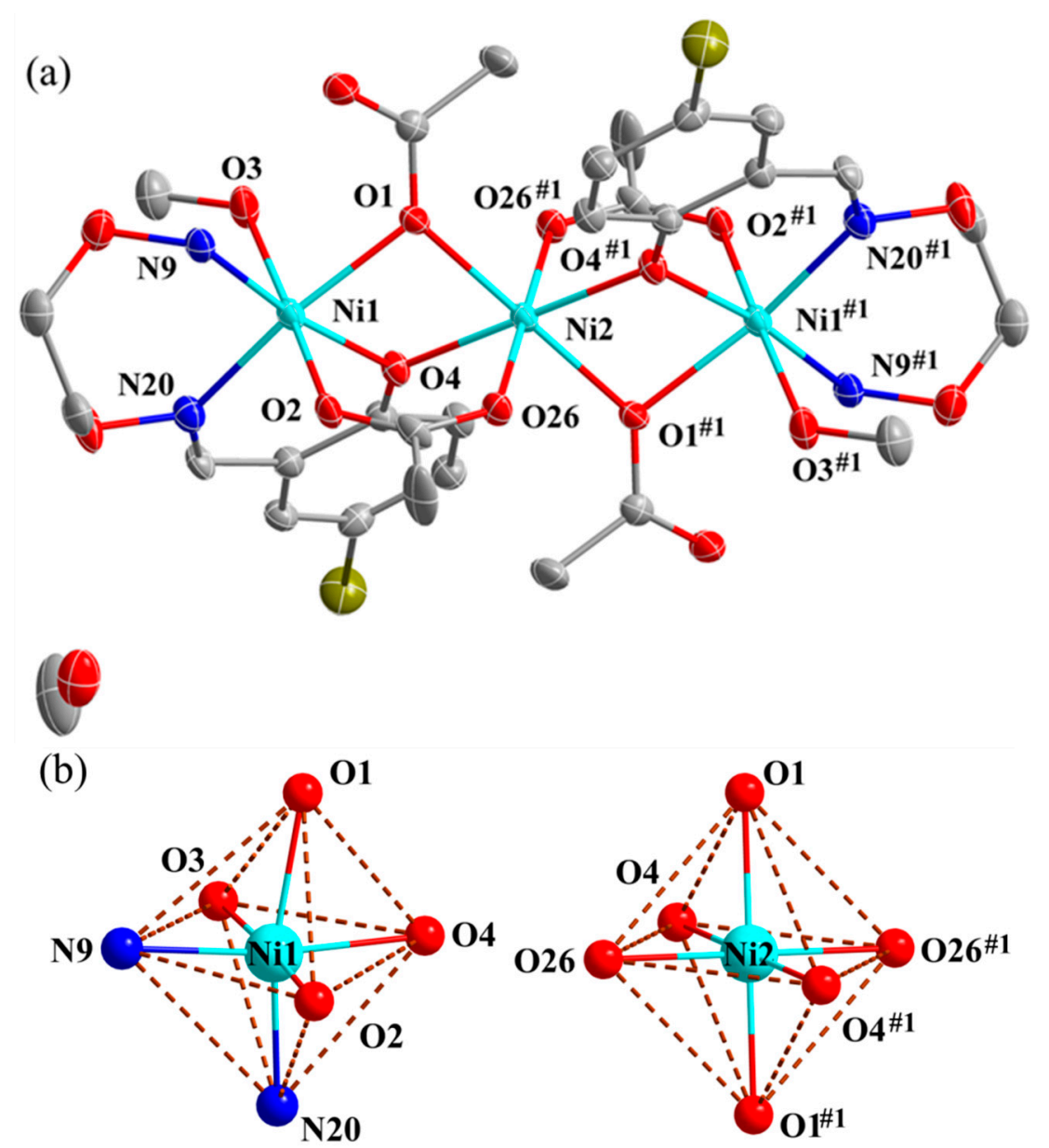

Figure 2. (a) Molecular structure of the Ni(II) complex with $30 \%$ probability displacement ellipsoids (hydrogen atoms are omitted for clarity); (b) coordination polyhedrons for $\mathrm{Ni}(\mathrm{II})$ atoms. 
Table 3. Bond lengths $(\AA)$ and angles $\left(^{\circ}\right)$ of the Ni(II) complex.

\begin{tabular}{|c|c|c|c|}
\hline Bond & Lengths & Bond & Lengths \\
\hline Ni1-O1 & $2.111(5)$ & Ni2-O1 & $2.076(5)$ \\
\hline $\mathrm{Ni}-\mathrm{O} 2$ & $2.009(5)$ & Ni2-O4 & $2.082(5)$ \\
\hline Ni1-O3 & $2.091(6)$ & $\mathrm{Ni} 2-\mathrm{O} 26$ & $2.078(6)$ \\
\hline $\mathrm{Ni1}-\mathrm{O} 4$ & $2.018(5)$ & $\mathrm{Ni} 2-\mathrm{O} 1{ }^{\# 1}$ & $2.076(5)$ \\
\hline Ni1-N9 & $2.036(6)$ & $\mathrm{Ni2}-\mathrm{O} 4{ }^{\# 1}$ & $2.082(5)$ \\
\hline Ni1-N20 & $2.065(8)$ & $\mathrm{Ni2}-\mathrm{O} 26^{\# 1}$ & $2.078(6)$ \\
\hline Bond & Angles & Bond & Angles \\
\hline O1-Ni1-O2 & $93.0(2)$ & O1-Ni2-O4 & $77.2(2)$ \\
\hline O1-Ni1-O3 & $86.8(2)$ & $\mathrm{O} 1-\mathrm{Ni} 2-\mathrm{O} 26$ & $89.1(2)$ \\
\hline O1-Ni1-O4 & $77.8(2)$ & O1-Ni2-O1 $\# 1$ & 180.00 \\
\hline O1-Ni1-N9 & $94.0(3)$ & $\mathrm{O} 1-\mathrm{Ni} 2-\mathrm{O} 4^{\# 1}$ & $102.8(2)$ \\
\hline O1-Ni1-N20 & $166.0(3)$ & O1-Ni2-O26 \#1 & $91.0(2)$ \\
\hline $\mathrm{O} 2-\mathrm{Ni1}-\mathrm{O} 3$ & $175.0(3)$ & $\mathrm{O} 4-\mathrm{Ni} 2-\mathrm{O} 26$ & $91.8(2)$ \\
\hline O2-Ni1-O4 & $93.0(2)$ & $\mathrm{O} 1^{\# 1}-\mathrm{Ni} 2-\mathrm{O} 4$ & $102.8(2)$ \\
\hline O2-Ni1-N9 & $87.5(3)$ & $\mathrm{O} 4-\mathrm{Ni} 2-\mathrm{O} 4^{\# 1}$ & 180.00 \\
\hline O2-Ni1-N20 & $92.1(3)$ & $\mathrm{O} 4-\mathrm{Ni} 2-\mathrm{O} 26^{\# 1}$ & $88.2(2)$ \\
\hline O3-Ni1-O4 & $91.8(2)$ & $\mathrm{O} 1{ }^{\# 1-N i 2-O} 26$ & $91.0(2)$ \\
\hline O3-Ni1-N9 & $87.6(3)$ & $\mathrm{O} 4^{\# 1}-\mathrm{Ni} 2-\mathrm{O} 26$ & $88.2(2)$ \\
\hline O3-Ni1-N20 & $89.3(3)$ & $\mathrm{O} 26-\mathrm{Ni2}-\mathrm{O} 266^{\# 1}$ & 180.00 \\
\hline O4-Ni1-N9 & $171.9(3)$ & $\mathrm{O} 1{ }^{\# 1-N i 2-O 4}{ }^{\# 1}$ & $77.2(2)$ \\
\hline O4-Ni1-N20 & $88.8(3)$ & $\mathrm{O} 1{ }^{\# 1-N i 2-O} 26{ }^{\# 1}$ & $89.1(2)$ \\
\hline N9-Ni1-N20 & $99.3(3)$ & $\mathrm{O} 4^{\# 1-N i 2-O} 26^{\# 1}$ & $91.8(2)$ \\
\hline
\end{tabular}

Symmetry transformations used to generate equivalent atoms: ${ }^{\# 1}-\mathrm{x}, 1-\mathrm{y},-\mathrm{z}$.

\subsection{Supra-Molecular Interactions}

As illustrated in Figure 3a, there are five pairs of different intra-molecular hydrogen bond

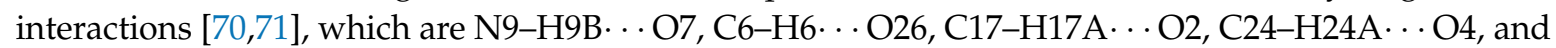
C25-H25A ‥ O22 intra-molecular interactions, and inter-molecular hydrogen bonding interactions (N9-H9A … O7 and C28-H28B ‥ O7) shown in Figure 3b, except for the hydrogen bonding formed, other hydrogen atoms were omitted. Hydrogen bonding interactions of the $\mathrm{Ni}$ (II) complex are summed in Table 4. The hydrogen bond interactions play a major role in the building of the $\mathrm{Ni}$ (II) complex. Through this inter-molecular hydrogen bonding inter-action, each molecule of the $\mathrm{Ni}$ (II) complex is connected to each other to gain a two-dimensional supra-molecular network along the $a b$ plane. At the same time, in Figure 3c, through the inter-molecular hydrogen bonding interactions, this network structure is connected to each other to gain an infinite three-dimensional supra-molecular structure.

Table 4. Hydrogen bonding interactions $\left(\AA^{\circ},{ }^{\circ}\right)$ of the Ni(II) complex.

\begin{tabular}{|c|c|c|c|c|}
\hline D-H $\cdots A$ & $d(D-H)$ & $d(H \cdots A)$ & $d(D \cdots A)$ & $\angle \mathrm{D}-\mathrm{H} \cdots \mathrm{A}$ \\
\hline N9-H9B $\cdots$ O7 & 0.90 & 2.00 & $2.808(10)$ & 149 \\
\hline C6-H6 ․ O26 & 0.93 & 2.52 & $3.202(10)$ & 131 \\
\hline C17-H17A $\cdots$ O2 & 0.97 & 2.48 & $3.372(11)$ & 153 \\
\hline C24-H24A ‥ O4 & 0.96 & 2.57 & $3.438(11)$ & 150 \\
\hline C25-H25A ‥ O22 & 0.96 & 2.48 & $3.178(13)$ & 130 \\
\hline N9-H9A …OO7 & 0.90 & 2.12 & $2.967(10)$ & 156 \\
\hline C28-H28A $\cdots$ O7 & 0.97 & 2.50 & $3.182(12)$ & 128 \\
\hline
\end{tabular}



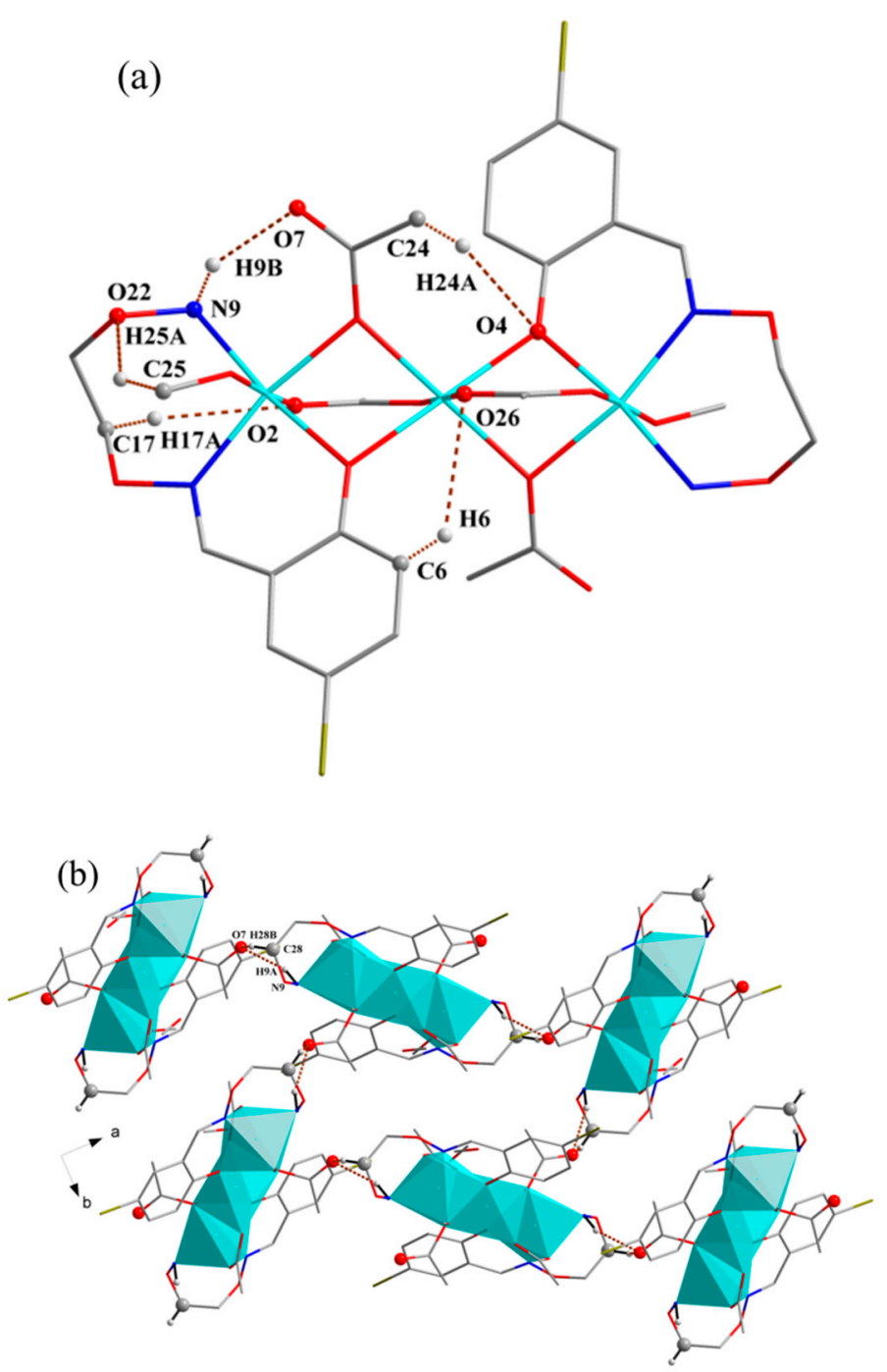

(c)
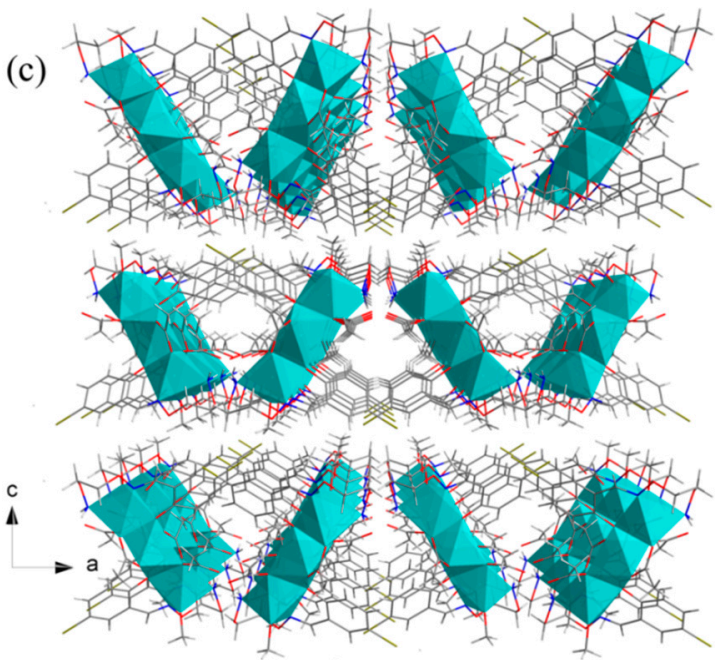

Figure 3. (a) View of the intra-molecular hydrogen bonding interactions of the Ni(II) complex (hydrogen atoms are omitted for clarity, except those forming hydrogen bondings); (b) View of the 2D supra-molecular structure of the $\mathrm{Ni}(\mathrm{II})$ complex; (c) view of the 3-D supra-molecular structure of the $\mathrm{Ni}(\mathrm{II})$ complex. 


\subsection{Fluorescence Titration Spectra}

As shown in the Figure 4, the fluorescence properties of $\mathrm{HL}$ and its Ni(II) complex in ethanol solvent were studied. The concentration of the ligand HL was $5.0 \times 10^{-5} \mathrm{M}$, the concentration of the $\mathrm{Ni}(\mathrm{II})$ ions was $1.0 \times 10^{-3} \mathrm{M}$, and the maximum excitation wavelength was about $315 \mathrm{~nm}$.

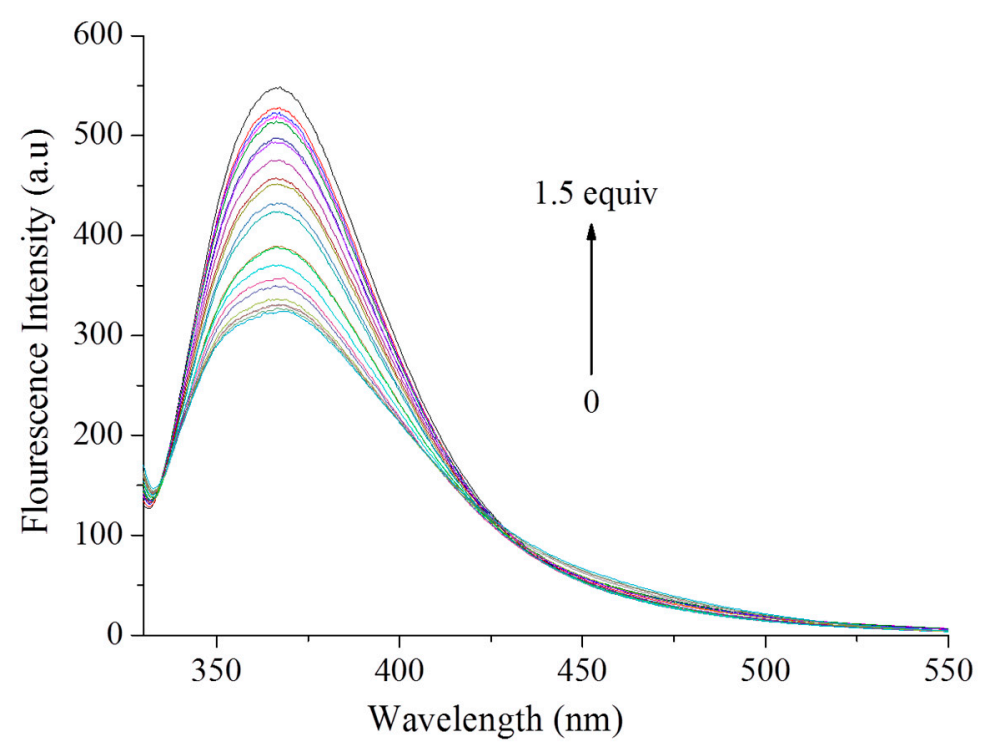

Figure 4. Fluorescence spectra of HL and its Ni(II) complex in ethanol upon excitation at $315 \mathrm{~nm}$.

When the excitation wavelength is $315 \mathrm{~nm}$, the ligand HL exhibits a strong absorption peak at $365 \mathrm{~nm}$, which is attributed to the $\pi-\pi^{*}$ transition. During the fluorescence titration experiment, the fluorescence intensity decreases as the concentration of the metal(II) ions increases. The decrease in fluorescence intensity was mainly owing to the bonding of the (L) ${ }^{-}$ligand with the $\mathrm{Ni}$ (II) ions. Compared with the emission spectrum of HL, the decrease in the fluorescence intensity of the complex was obtained, showing that the fluorescence was quenched due to the introduction of the $\mathrm{Ni}(\mathrm{II})$ atoms.

\subsection{Hirshfeld Surface Analysis}

Figure 5 shows the Hirshfeld surface distribution of the complex through $d_{n o r m}, d_{i}$, and $d_{e}$ mapping [72]. It can be clearly seen from the figure that the red region represents the $\mathrm{O}-\mathrm{H}$ between the $\mathrm{O}$ and $\mathrm{H}$ atoms in the $\mathrm{Ni}(\mathrm{II})$ complex. Inter-action intensity map, the heavier the color of the red region, the stronger the $\mathrm{O}-\mathrm{H}$ interactions, and the other shallower regions are mainly the distribution of short-range effects such as $\mathrm{C}-\mathrm{H}$ and $\mathrm{H}-\mathrm{H}$. From this figure, the distribution of the approximate hydrogen bondings in the complex can be analyzed, which is helpful to further explore the intrinsic factors of the stable existence of the complex.

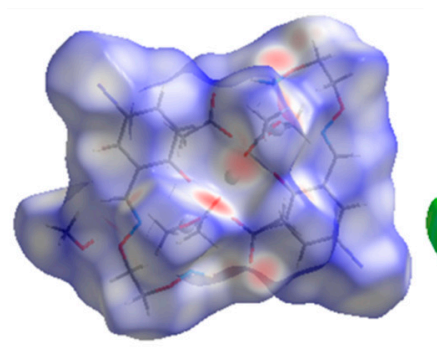

(a)

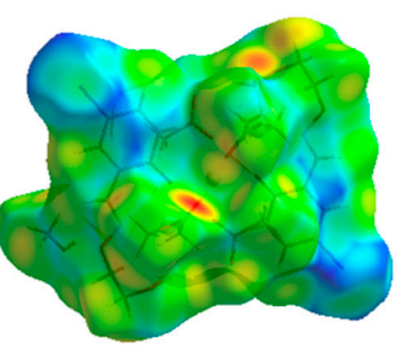

(b)

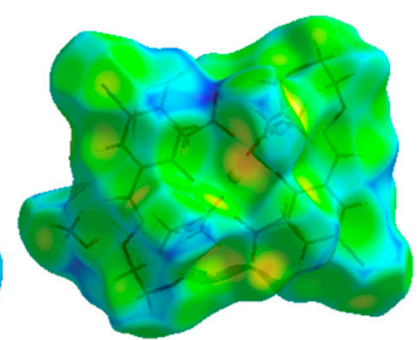

(c)

Figure 5. Hirshfeld surface analysis of the Ni(II) complex by $d_{n o r m}, d_{i}$, and $d_{e}$ mapping. 
In addition, the proportion of $\mathrm{C}-\mathrm{H} / \mathrm{H}-\mathrm{C}, \mathrm{O}-\mathrm{H} / \mathrm{H}-\mathrm{O}$, and $\mathrm{H}-\mathrm{H} / \mathrm{H}-\mathrm{H}$ in the complex can also be gained by Hirshfeld surface analysis. Here, we theoretically calculate the short-range action distribution inside the complex. As depicted in Figure 6, in this two-dimensional Hirshfeld surface generation map, the blue region represents the distribution of different interactions. For the entire $\mathrm{Ni}(\mathrm{II})$ complex molecule, the ratio of $\mathrm{C}-\mathrm{H} / \mathrm{H}-\mathrm{C}, \mathrm{O}-\mathrm{H} / \mathrm{H}-\mathrm{O}$, and $\mathrm{H}-\mathrm{H} / \mathrm{H}-\mathrm{H}$ in the surface of Hirshfeld was calculated to be $5.5 \%, 9.9 \%$, and $55.9 \%$, respectively. In fact, a complex can exist stably, and the short-range effects in these structures are indispensable.
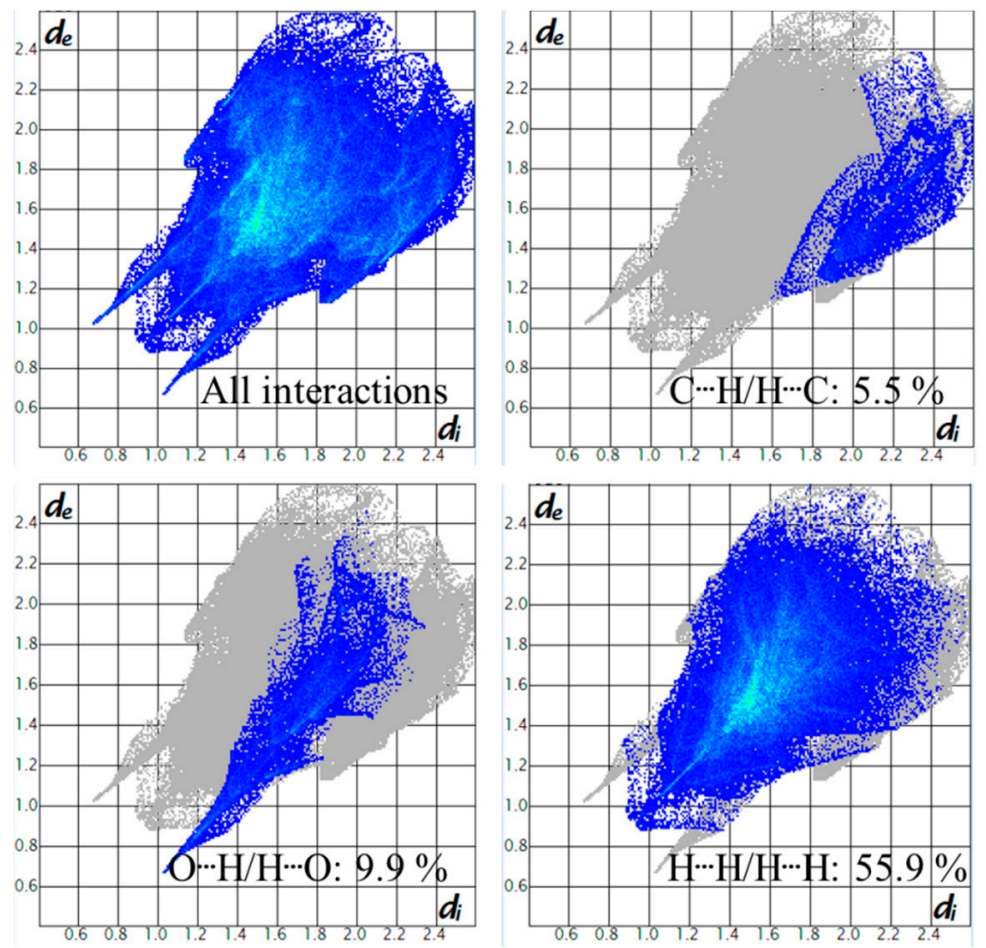

Figure 6. Finger-print plot of the proportion of short-range action on the Hirshfeld surface in the $\mathrm{Ni}(\mathrm{II})$ complex.

\section{Conclusions}

In summary, a new homo-trinuclear $\mathrm{Ni}(\mathrm{II})$ complex was designed and synthesized. X-ray crystallography reveals that the $\mathrm{Ni}(\mathrm{II})$ atoms in the complex are coordinated to two acetate molecules by two kinds of bidentate bridging and mono-dentate chelating coordination modes, which is a very rare phenomenon. The UV-Vis titration experiment clearly shows the ligand to $\mathrm{Ni}(\mathrm{II})$ ions has a stoichiometry of 2:3. Compared with HL, the fluorescence intensity of the complex was significantly lowered, indicating that the $\mathrm{Ni}(\mathrm{II})$ ions have fluorescence quenching characteristics. In addition, Hirshfeld surface analysis indicates that the $\mathrm{Ni}(\mathrm{II})$ complex can be stable owing to intra-molecular and inter-molecular hydrogen bonding interactions.

Author Contributions: W.-K.D. conceived and designed the experiments; X.-X.A. performed the experiments; Q.Z. and H.-R.M. analyzed the data; W.-K.D. contributed reagents/materials/analysis tools; X.-X.A. and Q.Z. wrote the paper.

Funding: This work was supported by the National Natural Science Foundation of China (Grant No. 21761018), and the Program for Excellent Team of Scientific Research in Lanzhou Jiaotong University (Grant No. 201706).

Conflicts of Interest: The authors declare no competing financial interests. 


\section{References}

1. Dong, Y.J.; Ma, J.C.; Zhu, L.C.; Dong, W.K.; Zhang, Y. Four 3d-4f heteromultinuclear zinc(II)-lanthanide(III) complexes constructed from a distinct hexadentate $\mathrm{N}_{2} \mathrm{O}_{2}$-type ligand: Syntheses, structures and photophysical properties. J. Coord. Chem. 2017, 70, 103-115. [CrossRef]

2. Dong, W.K.; Zhu, L.C.; Dong, Y.J.; Ma, J.C.; Zhang, Y. Mono, di and heptanuclear metal(II) complexes based on symmetric and asymmetric tetradentate salamo-type ligands: Syntheses, structures and spectroscopic properties. Polyhedron 2016, 117, 148-154. [CrossRef]

3. Dong, W.K.; Lan, P.F.; Zhou, W.M.; Zhang, Y. Salamo-type trinuclear and tetranuclear cobalt(II) complexes based on a new asymmetry salamo-type ligand: Syntheses, crystal structures, and fluorescence properties. J. Coord. Chem. 2016, 69, 1272-1283. [CrossRef]

4. Chai, L.Q.; Liu, G.; Zhang, Y.L.; Huang, J.J.; Tong, J.F. Synthesis, crystal structure, fluorescence, electrochemical property, and SOD-like activity of an unexpected nickel(II) complex with a quinazoline-type ligand. J. Coord. Chem. 2013, 66, 3926-3938. [CrossRef]

5. Ma, J.C.; Dong, X.Y.; Dong, W.K.; Zhang, Y.; Zhu, L.C.; Zhang, J.T. An unexpected dinuclear Cu(II) complex with a bis(salamo) chelating ligand: Synthesis, crystal structure, and photophysical properties. J. Coord. Chem. 2016, 69, 149-159. [CrossRef]

6. Wang, P.; Zhao, L. Synthesis, structure and spectroscopic properties of the trinuclear cobalt(II) and nickel(II) complexes based on 2-hydroxynaphthaldehyde and bis(aminooxy)alkane. Spectrochim. Acta A 2015, 135, 342-350. [CrossRef]

7. Peng, Y.D.; Wang, F.; Gao, L.; Dong, W.K. Structurally characterized dinuclearzinc(II) bis(salamo)-type tetraoximecomplex possessing square pyramidaland trigonal bipyramidal geometries. J. Chin. Chem. Soc. 2018, 65, 893-899. [CrossRef]

8. Wang, F.; Liu, L.Z.; Gao, L.; Dong, W.K. Unusual constructions of two salamo-based copper(II) complexes. Spectrochim. Acta A 2018, 203, 56-64. [CrossRef]

9. Li, X.Y.; Kang, Q.P.; Liu, L.Z.; Ma, J.C.; Dong, W.K. Trinuclear Co(II) and mononuclear Ni(II) salamo-type bisoxime coordination compounds. Crystals 2018, 8, 43. [CrossRef]

10. Gao, L.; Liu, C.; Wang, F.; Dong, W.K. Tetra-, penta- and hexa-coordinated transition metal complexes constructed from coumarin-containing $\mathrm{N}_{2} \mathrm{O}_{2}$ ligand. Crystals 2018, 8, 77. [CrossRef]

11. Dong, X.Y.; Gao, L.; Wang, F.; Zhang, Y.; Dong, W.K. Tri- and mono-nuclear zinc(II) complexes based on halfand mono-salamo chelating ligands. Crystals 2017, 7, 267. [CrossRef]

12. Zhang, L.W.; Liu, L.Z.; Wang, F.; Dong, W.K. Unprecedented fluorescent dinuclear $\mathrm{Co}^{\mathrm{II}}$ and $\mathrm{Zn}^{\mathrm{II}}$ coordination compounds with a symmetric bis(salamo)-like tetraoxime. Molecules 2018, 23, 1141. [CrossRef]

13. Li, X.Y.; Chen, L.; Gao, L.; Zhang, Y.; Akogun, S.F.; Dong, W.K. Syntheses, crystal structures and catalytic activities of two solvent-induced homotrinuclear Co(II) complexes with a naphthalenediol-based bis(salamo)-type tetraoxime ligand. RSC Adv. 2017, 7, 35905-35916. [CrossRef]

14. Li, L.H.; Dong, W.K.; Zhang, Y.; Akogun, S.F.; Xu, L. Syntheses, structures and catecholase activities of homo-and hetero-trinuclear cobalt(II) complexes constructed from an acyclic naphthalenediol-based bis(salamo)-type ligand. Appl. Organomet. Chem. 2017, 31, e3818. [CrossRef]

15. Chin, T.K.; Endud, S.; Jamil, S.; Budagumpi, S.; Lintang, H.O. Oxidative dimerization of o-aminophenol by heterogeneous mesoporous material modified with biomimetic salen-type copper(II) complex. Catal. Lett. 2013, 143, 282-288. [CrossRef]

16. Wu, H.L.; Bai, Y.C.; Zhang, Y.H.; Li, Z.; Wu, M.C.; Chen, C.Y.; Zhang, J.W. Synthesis, crystal structure, antioxidation and DNA-binding properties of a dinuclear copper(II) complex with bis(N-salicylidene)-3-oxapentane-1,5-diamine. J. Coord. Chem. 2014, 67, 3054-3066. [CrossRef]

17. Chen, C.Y.; Zhang, J.W.; Zhang, Y.H.; Yang, Z.H.; Wu, H.L.; Pan, G.L.; Bai, Y.C. Gadolinium(III) and dysprosium(III) complexes with a Schiff base bis( $N$-salicylidene)-3-oxapentane-1,5-diamine: Synthesis, characterization, antioxidation, and DNA-binding studies. J. Coord. Chem. 2015, 68, 1054-1071. [CrossRef]

18. Wu, H.L.; Wang, H.; Wang, X.L.; Pan, G.L.; Shi, F.R.; Zhang, Y.H.; Bai, Y.C.; Kong, J. V-shaped ligand bis(2-benzimidazolylmethyl)amine containing three copper(II) ternary complexes: Synthesis, structure, DNA binding properties and antioxidant activity. New J. Chem. 2014, 38, 1052-1061. [CrossRef] 
19. Zhang, Y.; Liu, L.Z.; Pan, Y.Q.; Dong, W.K. Structural characterized homotrinuclear Zn ${ }^{\mathrm{II}}$ bis(salamo)-based coordination compound: Hirshfeld surfaces, fluorescent and antimicobial properties. Crystals 2018, 8, 259. [CrossRef]

20. Zhang, H.; Xu, Y.L.; Wu, H.L.; Aderinto, S.O.; Fan, X.Y. Mono-, bi- and multi-nuclear silver complexes constructed from bis(benzimidazole)-2-oxapropane ligands and methacrylate: Syntheses, crystal structures, DNA-binding properties and antioxidant activities. RSC Adv. 2016, 6, 83697-83708. [CrossRef]

21. Hao, J.; Li, X.Y.; Wang, L.; Zhang, Y.; Dong, W.K. Luminescent and electrochemical properties of four novel butterfly-shaped hetero-pentanuclear $\left[\mathrm{Zn}_{4} \mathrm{Ln}\right]$ complexes constructed from a bis(salamo)-type ligand. Spectrochim. Acta A 2018, 204, 388-402. [CrossRef]

22. Dong, W.K.; Ma, J.C.; Zhu, L.C.; Zhang, Y.; Li, X.L. Four new nickel(II) complexes based on an asymmetric salamo-type ligand: Synthesis, structure, solvent effect and electrochemical property. Inorg. Chim. Acta 2016, 445, 140-148. [CrossRef]

23. Wang, L.; Hao, J.; Zhai, L.X.; Zhang, Y.; Dong, W.K. Synthesis, crystal structure, luminescence, electrochemical and antimicrobial properties of bis(salamo)-based Co(II) complex. Crystals 2017, 7, 277. [CrossRef]

24. Chai, L.Q.; Li, Y.X.; Chen, L.C.; Zhang, J.Y.; Huang, J.J. Synthesis, X-ray structure, spectroscopic, electrochemical properties and DFT calculation of a bridged dinuclear copper(II) complex. Inorg. Chim. Acta 2016, 444, 193-201. [CrossRef]

25. Zhang, H.; Dong, W.K.; Zhang, Y.; Akogun, S.F. Naphthalenediol-based bis(salamo)-type homo- and heterotrinuclear cobalt(II) complexes: Syntheses, structures and magnetic properties. Polyhedron 2017, 133, 279-293. [CrossRef]

26. Ren, Z.L.; Hao, J.; Hao, P.; Dong, X.Y.; Bai, Y.; Dong, W.K. Synthesis, crystal structure, luminescence and electrochemical properties of a salamo-type trinuclear cobalt(II) complex. Z. Naturforsch. B 2018, 73, $203-210$. [CrossRef]

27. Chai, L.Q.; Tang, L.J.; Chen, L.C.; Huang, J.J. Structural, spectral, electrochemical and DFT studies of two mononuclear manganese(II) and zinc(II) complexes. Polyhedron 2017, 122, 228-240. [CrossRef]

28. Sun, Y.X.; Zhao, Y.Y.; Li, C.Y.; Yu, B.; Guo, J.Q.; Li, J. Supramolecular cobalt(II) and copper(II) complexes with Schiff base ligand: Syntheses, characterizations and crystal structures. Chin. J. Inorg. Chem. 2016, 32, 913-920.

29. Jia, H.R.; Li, J.; Sun, Y.X.; Guo, J.Q.; Yu, B.; Wen, N.; Xu, L. Two supramolecular cobalt(II) complexes: Syntheses, crystal structures, spectroscopic behaviors, and counter anion effects. Crystals 2017, 7, 247.

30. Chang, J.; Zhang, H.J.; Jia, H.R.; Sun, Y.X. Binuclear nickel(II) and zinc(II) complexes based on 2-amino-3-hydroxy-pyridine Schiff base: Syntheses, supramolecular structures and spectral properties. Chin. J. Inorg. Chem. 2018, 34, 2097-2107.

31. Zhou, L.; Hu, Q.; Chai, L.Q.; Mao, K.H.; Zhang, H.S. X-ray characterization, spectroscopic, DFT calculations and hirshfeld surface analysis of two 3-D supramolecular mononuclear zinc(II) and trinuclear copper(II) complexes. Polyhedron 2019, 158, 102-116. [CrossRef]

32. Zhang, H.J.; Chang, J.; Jia, H.R.; Sun, Y.X. Syntheses, supramolecular structures and spectroscopic properties of $\mathrm{Cu}(\mathrm{II})$ and $\mathrm{Ni}(\mathrm{II})$ complexes with Schiff base containing oxime group. Chin. J. Inorg. Chem. 2018, 34, 2261-2270.

33. Jia, H.R.; Chang, J.; Zhang, H.J.; Li, J.; Sun, Y.X. Three polyhydroxyl-bridged defective dicubane tetranuclear $\mathrm{Mn}^{\mathrm{III}}$ complexes: Synthesis, crystal structures, and spectroscopic properties. Crystals 2018, 8, 272. [CrossRef]

34. Dong, Y.J.; Li, X.L.; Zhang, Y.; Dong, W.K. A highly selective visual and fluorescent sensor for $\mathrm{Pb}^{2+}$ and $\mathrm{Zn}^{2+}$ and crystal structure of $\mathrm{Cu}^{2+}$ complex based-on a novel single-armed salamo-type bisoxime. Supramol. Chem. 2017, 29, 518-527. [CrossRef]

35. Wang, F.; Gao, L.; Zhao, Q.; Zhang, Y.; Dong, W.K.; Ding, Y.J. A highly selective fluorescent chemosensor for $\mathrm{CN}^{-}$based on a novel bis(salamo)-type tetraoxime ligand. Spectrochim. Acta A 2018, 190, 111-115. [CrossRef]

36. Hu, J.H.; Sun, Y.; Qi, J.; Li, Q.; Wei, T.B. A new unsymmetrical azine derivative based on coumarin group as dual-modal sensor for $\mathrm{CN}^{-}$and fluorescent "OFF-ON" for $\mathrm{Zn}^{2+}$. Spectrochim. Acta A 2017, 175, 125-133. [CrossRef]

37. Dong, W.K.; Li, X.L.; Wang, L.; Zhang, Y.; Ding, Y.J. A new application of salamo-type bisoximes: As a relay-sensor for $\mathrm{Zn}^{2+} / \mathrm{Cu}^{2+}$ and its novel complexes for successive sensing of $\mathrm{H}^{+} / \mathrm{OH}^{-}$. Sens. Actuators $B$ 2016, 229, 370-378. [CrossRef] 
38. Wang, B.J.; Dong, W.K.; Zhang, Y.; Akogun, S.F. A novel relay-sensor for highly sensitive and selective detection of $\mathrm{Zn}^{2+} / \mathrm{Pic}^{-}$and fluorescence on/off switch response of $\mathrm{H}^{+} / \mathrm{OH}^{-}$. Sens. Actuators B 2017, 247, 254-264. [CrossRef]

39. Dong, W.K.; Akogun, S.F.; Zhang, Y.; Sun, Y.X.; Dong, X.Y. A reversible "turn-on" fluorescent sensor for selective detection of $\mathrm{Zn}^{2+}$. Sens. Actuators B 2017, 238, 723-734. [CrossRef]

40. Sun, Y.; Hu, J.H.; Qi, J.; Li, J.B. A highly selective colorimetric and "turn-on" fluorimetric chemosensor for detecting $\mathrm{CN}^{-}$based on unsymmetrical azine derivatives in aqueous media. Spectrochim. Acta A 2016, 167, 101-105. [CrossRef]

41. Zhang, L.W.; Li, X.Y.; Kang, Q.P.; Liu, L.Z.; Ma, J.C.; Dong, W.K. Structures and fluorescent and magnetic behaviors of newly synthesized $\mathrm{Ni}^{\mathrm{II}}$ and $\mathrm{Cu}{ }^{\mathrm{II}}$ coordination compounds. Crystals 2018, 8, 173. [CrossRef]

42. Dong, W.K.; Ma, J.C.; Dong, Y.J.; Zhu, L.C.; Zhang, Y. Di- and tetranuclear heterometallic 3d-4f cobalt(II)-lanthanide(III) complexes derived from a hexadentate bisoxime: Syntheses, structures and magnetic properties. Polyhedron 2016, 115, 228-235. [CrossRef]

43. Liu, P.P.; Sheng, L.; Song, X.Q.; Xu, W.Y.; Liu, Y.A. Synthesis, structure and magnetic properties of a new one dimensional manganese coordination polymer constructed by a new asymmetrical ligand. Inorg. Chim. Acta 2015, 434, 252-257. [CrossRef]

44. Li, J.; Zhang, H.J.; Chang, J.; Jia, H.R.; Sun, Y.X.; Huang, Y.Q. Solvent-induced unsymmetric salamo-like trinuclear $\mathrm{Ni}^{\mathrm{II}}$ complexes: Syntheses, crystal structures, fluorescent and magnetic properties. Crystals 2018, 8, 176. [CrossRef]

45. Song, X.Q.; Liu, P.P.; Wang, C.Y.; Liu, Y.A.; Liu, W.S.; Zhang, M. Three sandwich-type zinc(II)-lanthanide(III) clusters: Structures, luminescence and magnetic properties. RSC Adv. 2017, 7, 22692-22698. [CrossRef]

46. Zheng, S.S.; Dong, W.K.; Zhang, Y.; Chen, L.; Ding, Y.J. Four salamo-type 3d-4f hetero-bimetallic $\left[\mathrm{Zn}^{\mathrm{II}} \mathrm{Ln}^{\mathrm{III}}\right]$ complexes: Syntheses, crystal structures, and luminescent and magnetic properties. New J. Chem. 2017, 41, 4966-4973. [CrossRef]

47. Dong, W.K.; Ma, J.C.; Zhu, L.C.; Zhang, Y. Nine self-assembled nickel(II)-lanthanide(III) heterometallic complexes constructed from a salamo-type bisoxime and bearing $\mathrm{N}$ - or $\mathrm{O}$-donor auxiliary ligand: Syntheses, structures and magnetic properties. New J. Chem. 2016, 40, 6998-7010. [CrossRef]

48. Guo, J.Q.; Sun, Y.X.; Yu, B.; Li, J.; Jia, H.R. Syntheses, crystal structures and spectroscopic properties of copper(II) and nickel(II) complexes with oxime-type Schiff base ligands. Chin. J. Inorg. Chem. 2017, 33, 1481-1488.

49. Dong, X.Y.; Zhao, Q.; Kang, Q.P.; Mu, H.R.; Zhang, H.; Dong, W.K. Self-assembly of 3d-4f Zn ${ }^{I I}-L^{I I I}(\operatorname{Ln}=$ Ho and Er) bis(salamo)-based complexes: Controlled syntheses, structures and fluorescence properties. Crystals 2018, 8, 230. [CrossRef]

50. Peng, Y.D.; Li, X.Y.; Kang, Q.P.; An, G.X.; Zhang, Y.; Dong, W.K. Synthesis and fluorescence properties of asymmetrical salamo-type tetranuclear zinc(II) complex. Crystals 2018, 8, 1079.

51. Dong, X.Y.; Zhao, Q.; Wei, Z.L.; Mu, H.R.; Zhang, H.; Dong, W.K. Synthesis and fluorescence properties of structurally characterized heterobimetalic $\mathrm{Cu}(\mathrm{II})-\mathrm{Na}(\mathrm{I})$ bis(salamo)-based complex bearing square planar, square pyramid and triangular prism geometries of metal centers. Molecules 2018, 23, 1006. [CrossRef]

52. Kang, Q.P.; Li, X.Y.; Zhao, Q.; Ma, J.C.; Dong, W.K. Structurally characterized homotrinuclear salamo-type nickel(II) complexes: Synthesis, solvent effect and fluorescence properties. Appl. Organomet. Chem. 2018, 32, e4379. [CrossRef]

53. Hao, J.; Li, X.Y.; Zhang, Y.; Dong, W.K. A reversible bis(salamo)-based fluorescence sensor for selective detection of $\mathrm{Cd}^{2+}$ in water-containing systems and food samples. Materials 2018, 11, 523. [CrossRef]

54. Wang, L.; Kang, Q.P.; Hao, J.; Dong, W.K. Two trinuclear cobalt(II) salamo-type complexes: Syntheses, crystal structures, solvent effect and fluorescent properties. Chin. J. Inorg. Chem. 2018, 34, 525-533.

55. Chen, L.; Dong, W.K.; Zhang, H.; Zhang, Y.; Sun, Y.X. Structural variation and luminescence properties of triand dinuclear $\mathrm{Cu}^{\mathrm{II}}$ and $\mathrm{Zn}^{\mathrm{II}}$ complexes constructed from a naphthalenediol-based bis(salamo)-type ligand. Cryst. Growth Des. 2017, 17, 3636-3648. [CrossRef]

56. Wang, L.; Li, X.Y.; Zhao, Q.; Li, L.H.; Dong, W.K. Fluorescence properties of heterotrinuclear Zn(II)-M(II) ( $\mathrm{M}=\mathrm{Ca}$, Sr and Ba) bis(salamo)-type complexes. RSC Adv. 2017, 7, 48730-48737. [CrossRef]

57. Li, X.Y.; Liu, C.; Gao, L.; Sun, Y.X.; Zhang, Y.; Dong, W.K. Syntheses, structures, hirshfeld surface analyses and magnetic properties of a series of homopolynuclear half-salamo-based complexe. Polyhedron 2018, 155, 320-331. [CrossRef] 
58. Hao, J.; Li, L.L.; Zhang, J.T.; Akogun, S.F.; Wang, L.; Dong, W.K. Four homo- and hetero-bismetallic 3d/3d-2s complexes constructed from a naphthalenediol-based acyclic bis(salamo)-type tetraoxime ligand. Polyhedron 2017, 134, 1-10. [CrossRef]

59. Pu, L.M.; Long, H.T.; Zhang, Y.; Bai, Y.; Dong, W.K. Three new salamo-type homotrinuclear nickel(II) complexes possessing solvent effects: Syntheses, structures and fluorescence properties. Polyhedron 2017, 128, 57-67. [CrossRef]

60. Tao, C.H.; Ma, J.C.; Zhu, L.C.; Zhang, Y.; Dong, W.K. Heterobimetallic 3d-4f Zn(II)-Ln(III) (Ln = Sm, Eu, $\mathrm{Tb}$ and $\mathrm{Dy}$ ) complexes with a $\mathrm{N}_{2} \mathrm{O}_{4}$ bisoxime chelate ligand and a simple auxiliary ligand Py: Syntheses, structures and luminescence properties. Polyhedron 2017, 128, 38-45. [CrossRef]

61. Gao, L.; Wang, F.; Zhao, Q.; Zhang, Y.; Dong, W.K. Mononuclear Zn(II) and trinuclear Ni(II) complexes derived from a coumarin-containing $\mathrm{N}_{2} \mathrm{O}_{2}$ ligand: Syntheses, crystal structures and fluorescence properties. Polyhedron 2018, 139, 7-16. [CrossRef]

62. Madison, W.I. SAINT-Plus, Bruker Analytical X-ray System; Bruker: Billerica, MA, USA, 1999.

63. Sheldrick, G.M. SADABS, Program for Empirical Absorption Correction of Area Detector Data; University of Gottingen: Gottingen, Germany, 1996.

64. Dong, X.Y.; Kang, Q.P.; Jin, B.X.; Dong, W.K. A dinuclear nickel(II) complex derived from an asymmetric salamo-type $\mathrm{N}_{2} \mathrm{O}_{2}$ chelate ligand: Synthesis, structure and optical properties. Z. Naturforsch. B 2017, 72, 415-420. [CrossRef]

65. Wang, P.; Zhao, L. An infinite 2D supramolecular cobalt(II) complex based on an asymmetric salamo-type ligand: Synthesis, crystal structure, and spectral properties. Synth. React. Inorg. Met.-Org. Nano-Met. Chem. 2016, 46, 1095-1101. [CrossRef]

66. Yang, Y.H.; Hao, J.; Dong, Y.J.; Wang, G.; Dong, W.K. Two znic(II) complexes constructed from a bis(salamo)-type tetraoxime ligand: Syntheses, crystal structures and luminescence properties. Chin. J. Inorg. Chem. 2017, 33, 1280-1292.

67. Wu, H.L.; Bai, Y.C.; Zhang, Y.H.; Pan, G.L.; Kong, J.; Shi, F.; Wang, X.L. Two lanthanide(III) complexes based on the Schiff base N,N-bis(salicylidene)-1,5-diamino-3-oxapentane: Synthesis, characterization, DNA-binding properties, and antioxidation. Z. Anorg. Allg. Chem. 2014, 640, 2062-2071. [CrossRef]

68. Song, X.Q.; Liu, P.P.; Liu, Y.A.; Zhou, J.J.; Wang, X.L. Two dodecanuclear heterometallic $\left[\mathrm{Zn}^{6} \mathrm{Ln}^{6}\right]$ clusters constructed by a multidentate salicylamide salen-like ligand: Synthesis, structure, luminescence and magnetic properties. Dalton Trans. 2016, 45, 8154-8163. [CrossRef]

69. Hu, J.H.; Chen, J.J.; Li, J.B.; Qi, J. A cyanide ion probe based on azosalicylic aldehyde of benzoyl hydrazone. Chin. J. Inorg. Chem. 2014, 30, 2544-2548.

70. Dong, W.K.; Zheng, S.S.; Zhang, J.T.; Zhang, Y.; Sun, Y.X. Luminescent properties of heterotrinuclear 3d-4f complexes constructed from a naphthalenediol-based acyclic bis(salamo)-type ligand. Spectrochim. Acta A 2017, 184, 141-150. [CrossRef]

71. Dong, X.Y.; Kang, Q.P.; Li, X.Y.; Ma, J.C.; Dong, W.K. Structurally characterized solvent-induced homotrinuclear cobalt(II) $\mathrm{N}_{2} \mathrm{O}_{2}$-donor bisoxime-type complexes. Crystals 2018, 8, 139. [CrossRef]

72. Spackman, M.A.; McKinnon, J.J.; Jayatilaka, D. Electrostatic potentials mapped on hirshfeld surfaces provide direct insight into intermolecular interactions in crystals. Cryst. Eng. Commun. 2008, 10, 377-388. [CrossRef]

(C) 2019 by the authors. Licensee MDPI, Basel, Switzerland. This article is an open access article distributed under the terms and conditions of the Creative Commons Attribution (CC BY) license (http:/ / creativecommons.org/licenses/by/4.0/). 